Jurnal Fokus Manajemen Bisnis
Unolume 11, Nomor 2, September 2021, Halaman 189-199
https://doi.org/10.12928//fokus.v11i2.4584
http://journal2.uad.ac.id/index.php/fokus
Ahmad Dahlan

\title{
EFEK LINGKUNGAN KERJA DAN EFIKASI DIRI PADA KINERJA KARYAWAN
}

\author{
Ulfa Sofiatun', Anwar Mansyur ${ }^{2, *}$ \\ Universitas Stikubank, Semarang, Indonesia \\ a.n.mansyur@gmail.com \\ *Correspondent Author
}

Article History

Received 2021-07-30

Revised 2021-08-03

Accepted 2021-08-03

Keywords

Work Environment

Self-Efficacy

Employee Performance
This study aims to examine the effect of work environment and self-efficacy on employee performance. The object of this research is a historical and tourism site in the Semarang City, namely the Sam Poo Kong Temple and Lawang Sewu. The research was conducted in quantitative method by distributing questionnaire to the employee in the both locations. The sampling method that purposive sampling technique with the criteria of respondents are employee has been working for at least one year. Based on the data collection, a sample of 107 employees was obtained to be analyzed. The data were analyzed using regression analysis method. The results of the study strengthen the findings of previous studies that work environment and self-efficacy have a positive effect on employee performance.

This is an open-access article under the CC-BY-SA license.

\section{Pendahuluan}

Employee engagement dalam proses pencapaian tujuan organisasi merupakan hal yang tidak dapat dihindarkan. Ram \& Prabhakar (2011) mengungkapkan bahwa keterlibatan karyawan (employee engagement) akan mendorong proses perbaikan organisasi yang mampu menunjang keunggulan kompetitif yang berkelanjutan. Keterlibatan karyawan memberikan pengaruh yang besar dalam mencapai kinerja, baik individu maupun organisasi. Anitha (2014) menyatakan bahwa keterlibatan karyawan merupakan tingkat komitmen dan partisipasi yang dimiliki oleh karyawan terhadap nilai-nilai organisasi. Komitmen dan partisipasi karyawan secara langsung akan berdampak pada kinerja.

Peningkatan kinerja karyawan menjadi hal penting bagi organisasi untuk meningkatkan nilai organisasi. Kinerja karyawan yang semakin baik, tentu saja akan memberikan dampak secara langsung terhadap peningkatan kinerja organisasi (Ali \& Hasaballah, 2020). Kinerja karyawan diukur melalui efektivitas penyelesaian tugas dan output serta outcomes yang diperoleh dalam periode waktu tertentu.

Penelitian terdahulu terkait dengan lingkungan kerja dan efikasi diri lebih banyak dilakukan pada sektor jasa (Danish et al., 2013; Dul \& Ceylan, 2014; Agbozo et al., 2017) yang memiliki kondisi lingkungan kerja fisik yang stabil. Contohnya sektor perbankan yang sudah memiliki prosedur standar operasi sifatnya stagnan sehingga mampu menimbulkan kebosanan dan aktivitas yang monoton (Schultz \& Schultz, 2016). Individu dan lingkungan memberikan penegasan bahwa hal tersebut dapat berjalan dengan baik melalui pemahaman dan pengalaman individu. Tentu saja hal ini akan berbeda ketika lingkungan kerja yang merupakan situs sejarah. Ada hal-hal yang harus tetap dijaga 
dalam lingkungan situs warisan budaya, karena faktor historis (Poria et al., 2004). Lingkungan dan sosio-kultural menjadi hal utama untuk menarik calon wisatawan (Kempiak et al., 2017). Hal ini memberikan tantangan tersendiri bagi pengelola dan karyawan agar menciptakan lingkungan kerja yang baik tanpa merusak situs sejarah, seperti Klenteng Sam Poo Kong dan Lawang Sewu di Kota Semarang.

Klenteng Sam Poo Kong dan Lawang Sewu merupakan objek wisata andalan Kota Semarang, selain karena letaknya yang sangat strategis, objek ini memiliki nilai sejarah yang cukup panjang. Ini menjadi penting karena untuk menjaga eksistensi dan informasi yang akurat terkait lingkungan (termasuk lingkungan kerja), maka diperlukan karyawan yang memiliki kemampuan dan keterampilan baik (Agbozo et al., 2017). Hal lain yang menjadi sorotan lingkungan organisasi yang semakin tidak terawat. Kondisi ini tentu saja akan mempengaruhi kualitas kerja karyawan dan akan berdampak pada jumlah kunjungan ke situs-situs tersebut. Dul \& Ceylan (2014) menjelaskan bahwa lingkungan kerja mampu melahirkan kreativitas dalam penyelesaian tugas sehingga pekerjaan yang karyawan kerjakan dapat menghasilkan nilai yang positif bagi organisasi.

Beberapa penelitian menghasilkan temuan berbeda, baik dari penelitian sebelumnya maupun dari teori yang sudah mapan. Teori sosial kognitif (cognitive social theory) membahas asal usul efikasi diri, struktur dan fungsinya terhadap perilaku kerja karyawan (Bandura, 2012). Lebih lanjut dijelaskan bahwa teori ini tidak hanya memberikan pengalaman, namun dapat memprediksi perubahan perilaku kerja. Talsma et al. (2019) akurasi efikasi diri tidak dapat diukur dengan tetap, karena dianggap belum mampu memprediksi arah hubungan perilaku karyawan. Temuan yang dikemukakan oleh Tzur et al. (2016) efektivitas efikasi diri dipengaruhi oleh faktor lain, seperti penghargaan. Apabila penghargaan meningkat, maka efikasi diri karyawan akan semakin baik terhadap pencapaian kinerja, begitu juga sebaliknya. Oleh karena itu, Tzur et al. (2016) mengungkapkan bahwa efikasi diri tidak mampu mempengaruhi kinerja secara langsung.

Kondisi tersebut menjadi perhatian khusus untuk memberikan klarifikasi secara empiris terkait efek lingkungan kerja dan efikasi diri terhadap kinerja karyawan. Hal tersebut dianggap penting agar temuan penelitian ini mampu memperkuat sinkronisasi teori sosial kognitif dan temuan empiris sebelumnya, khususnya dalam konteksnya yang lebih luas seperti industri pariwisata.

\section{Review Literatur dan Hipotesis}

\subsection{Landasan Teori}

\subsubsection{Lingkungan Kerja}

Lingkungan kerja merupakan suatu kondisi yang terkait dengan karakteristik tempat kerja terhadap perilaku dan sikap karyawan (Schultz \& Schultz, 2016). Tempat kerja yang baik memiliki karakteristik umum seperti gaji yang kompetitif, hubungan saling percaya antar karyawan dan manajemen organisasi, kesetaraan dan keadilan untuk semua pihak dalam organisasi, beban kerja yang proprosional (Agbozo et al., 2017). Schultz \& Schultz (2016) serta Agbozo et al. (2017) mengelompokkan lingkungan kerja dalam tiga bentuk yaitu: 
1. Lingkungan Kerja Fisik

Lingkungan kerja fisik merupakan lingkungan yang berkaitan dengan hal yang sifatnya berwujud. Hal tersebut seperti tata letak kantor, ventilasi, pencahayaan, dan hal fisik lainnya yang mampu mempengaruhi karyawan.

2. Lingkungan Kerja Psikologis

Lingkungan kerja psikologis adalah seperangkat karakteristik lingkungan kerja yang mempengaruhi perasaan karyawan. Misalnya, emosi, suasana hati, kognisi, dan perilaku.

3. Lingkungan Kerja Sosial

Lingkungan sosial mencakup gaya komunikasi, hubungan antar sesama karyawan, hubungan antara karyawan dengan atasan, kerja tim, dan kesediaan rekan kerja untuk saling membantu.

\subsubsection{Efikasi Diri}

Efikasi diri merupakan keyakinan tentang kepercayaan akan keterampilan dan kemampuan diri seseorang dalam menyelesaikan tugas (Carter et al., 2018). Efikasi diri mengacu pada penilaian seseorang tentang kemampuannya untuk memotivasi, memobilisasi sumber daya kognitif dan tindakan yang dibutuhkan untuk memenuhi tuntutan kondisi tertentu (Bandura, 2012). Efikasi diri mencerminkan kapasitas individu untuk mengelola segala potensi yang dimiliki dalam menghadapi situasi tertentu.

Redifer et al. (2021) mengungkapkan bahwa efikasi diri adalah faktor perbedaan individu yang mengacu pada keyakinan tentang kemampuan seseorang untuk berhasil dalam tugas. Lebih lanjut dijelaskan bahwa akurasi efikasi diri akan berdampak pada kinerja (Talsma et al., 2019). Cherian \& Jacob (2013) menyatakan bahwa terdapat empat indikator dari efikasi diri yaitu sifat individu, jenis kelamin, budaya, dan karakteristik tugas.

\subsubsection{Kinerja Karyawan}

Kinerja karyawan pada dasarnya adalah hasil yang dicapai dan prestasi yang dibuat di tempat kerja (Anitha, 2014). Kinerja karyawan terdiri dari enam indikator (Robbins \& Judge, 2015). Pertama, kualitas kerja yang merupakan kesesuaian standar kerja untuk bidang pekerjaan tertentu. Pekerjaan yang berkualitas adalah pekerjaan yang dapat diselesaikan sesuai dengan spesifikasi pekerjaan. Kedua, kuantitas kerja merupakan jumlah output yang dihasilkan oleh karyawan dalam menyelesaikan pekerjaan. Pekerjaan yang baik adalah pekerjaan yang mampu menghasilkan standar output yang menjadi target karyawan.

Ketiga, ketepatan waktu. Kinerja seorang karyawan dikatakan baik apabila kualitas dan kuantitas kerja diselesaikan dengan standar waktu yang telah ditetapkan oleh organisasi. Keempat, efektivitas kerja yang merupakan upaya pemanfaatan sumber daya yang sesuai dengan kebutuhan dalam menghasilkan output. Kelima, kemandirian. Karyawan yang memiliki kinerja yang baik adalah karyawan yang mampu bekerja secara individu dan tim tanpa bergantung pada karyawan lain; dan terakhir adalah keinginan untuk berkembang. Karyawan yang berkinerja baik, selalu memposisikan dirinya sebagai pembelajar, khususnya dari pengalaman serta hal-hal baru yang dapat menunjang kinerja karyawan dalam menyelesaikan tugas dan tanggung jawab dari organisasi. 


\subsection{Hipotesis}

\subsubsection{Pengaruh Positif Lingkungan Kerja terhadap Kinerja Karyawan}

Chandrasekar (2011) mengungkapkan bahwa lingkungan kerja yang kondusif akan memberikan dampak pada produktivitas karyawan. Lingkungan kerja yang nyaman, bersih dan tertata dengan baik, secara fisik akan membantu meningkatkan optimisme dan suasana hati untuk bekerja dengan maksimal. Lingkungan kerja menjadi salah faktor signifikan untuk meningkatkan kinerja individu maupun organisasi (Anitha, 2014). Lamb \& Kwok (2016) menemukan bukti empiris bahwa tingkat reduksi stres kerja yang diakibatkan oleh kondisi psikologis sesama karyawan yang saling mendukung memberikan kontribusi yang signifikan pada kinerja. Oleh karena itu, semakin kondusif iklim kerja di lingkungan kerja akan memberikan kontribusi pada peningkatan kinerja pada karyawan (Supriyanto dkk, 2020). Berdasarkan temuan tersebut, dikembangkan hipotesis sebagai berikut:

\section{$\mathrm{H}_{1}$ : Lingkungan Kerja Berpengaruh Positif terhadap Kinerja Karyawan}

\subsubsection{Pengaruh Positif Efikasi Diri terhadap Kinerja Karyawan}

Karakteristik karyawan dianggap mampu memberikan kontribusi positif pada organisasi. Carter et al. (2018) menyatakan bahwa efikasi diri dan keterlibatan karyawan sangat penting bagi pencapaian kinerja. Bandura (2012) mengungkapkan bahwa secara umum efikasi diri karyawan mampu meningkatkan kinerja. Temuan tersebut didukung oleh penelitian sebelumnya yang menyatakan bahwa semakin baik efikasi diri seorang karyawan, maka kinerja karyawan dan organisasi akan mengalami peningkatan (Cherian \& Jacob, 2013; Carter et al., 2018; dan Redifer et al., 2021). Berdasarkan hasil temuan empiris penelitian sebelumnya, maka diduga bahwa efikasi diri mempengaruhi kinerja karyawan. Oleh sebab itu, dikembangkan hipotesis sebagai berikut:

\section{$\mathrm{H}_{2}$ : Efikasi Diri Berpengaruh Positif terhadap Kinerja Karyawan}

\subsection{Model Penelitian}

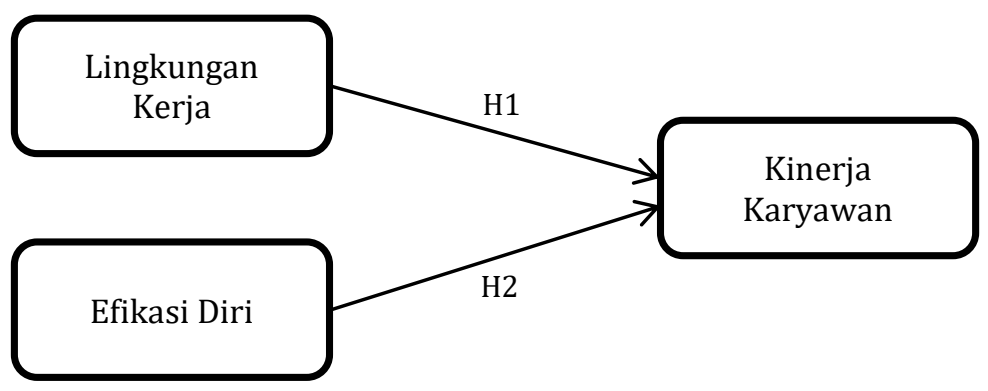

Gambar 1. Model Penelitian

\section{Metode Penelitian}

\subsection{Populasi dan Sampel}

Objek penelitian yang digunakan dalam penelitian ini adalah Klenteng Sam Poo Kong dan Lawang Sewu. Klenteng Sam Poo Kong berada di Jalan Simongan 129, Bongsari, Kecamatan Semarang Barat, Kota Semarang dan Lawang Sewu berada di Jalan Pemuda, Sekayu, Kecamatan Semarang Tengah, Kota Semarang. Populasi yang digunakan adalah karyawan yang bekerja di kedua objek wisata tersebut. Teknik pengambilan sampel yang digunakan adalah teknik nonprobability sampling atau teknik penentuan sampel yang tidak memberikan peluang yang sama bagi anggota populasi untuk dijadikan sampel (Sugiyono, 2013). Jenis teknik nonprobability yang 
digunakan adalah teknik purposive sampling atau penentuan sampel dengan menggunakan kriteria tertentu, yaitu karyawan yang telah bekerja minimal satu tahun. Berdasarkan teknik tersebut diperoleh sampel sebanyak 107 responden.

\subsection{Teknik Pengumpulan Data}

Data yang diperoleh melalui pendistribusian kuesioner kepada karyawan yang memenuhi syarat. Kuesioner didistribusikan secara daring dengan bantuan pengelola Klenteng Sam Poo Kong dan Lawang Sewu. Pengukuran item pernyataan dalam kuesioner menggunakan skala Likert dengan rentang 1 sampai dengan 5 . Nilai 1 berarti sangat tidak setuju, 2 berarti tidak setuju, 3 berarti netral, 4 berarti setuju, dan nilai 5 berarti sangat setuju. Lingkungan kerja diukur dengan menggunakan 5 item pernyataan yang dikembangkan oleh Kacmar et al. (2009), efikasi diri diukur menggunakan 5 item pernyataan dari Schmidt \& DeShon (2010), dan kinerja karyawan diukur menggunakan 7 item pernyataan dari Kacmar et al. (2009).

\subsection{Uji Validitas dan Uji Reliabilitas}

Namun sebelum melakukan pengujian model, terlebih dahulu dilakukan uji validitas dan uji reliabilitas. Uji validitas menggunakan pengujian analisis faktor dengan metode konfirmatori. Konstruk dikatakan valid apabila nilai factor loading lebih besar dari 0,5 dan tidak terjadi cross loading antar komponen dalam setiap konstruk (Hair et al., 2009). Pengujian selanjutnya adalah uji reliabilitas. Instrumen dikatakan reliabel apabila nilai cronbach's alpha-nya lebih besar sama dengan 0,6 (Hair et al., 2009).

\subsection{Teknik Analisis Data}

Pengujian model menggunakan analisis regresi linier berganda dengan bantuan aplikasi SPSS versi 24. Penelitian ini menggunakan analisa nilai koefisien determinasi, uji simultan dan uji parsial. Nilai koefisien determinasi bertujuan untuk melihat variasi keseluruhan variabel independen terhadap variabel dependen. Kemudian dilakukan uji simultan yang bertujuan untuk melihat pengaruh keseluruhan variabel independen terhadap variabel dependen. Uji Simultan dilakukan dengan melihat perbandingan nilai f-hitung dengan f-tabel. Apabila nilai f-hitung lebih besar dari nilai f-tabel, maka secara simultan variabel independen memiliki pengaruh terhadap variabel dependen. Hal yang sama juga berlaku untuk pengujian parsial. Uji parsial dilakukan dengan membandingkan nilai t-hitung dengan nilai t-tabel. Variabel independen berpengaruh secara parsial terhadap variabel dependen apabila nilai thitung lebih besar dari nilai t-tabel. Selain, perbandingan nilai f-hitung dan nilai thitung dan nilai f-tabel dan nilai t-tabel, pengujian dapat dilakukan dengan melihat level signifikansi. Nilai standar signifikansi yang digunakan dalam penelitian sosial adalah nilai yang berada di bawah atau sama dengan 0,05 (Hair et al., 2009). Lebih lanjut, (Hair et al., 2009) menyatakan bahwa semakin kecil nilai signifikansi, maka hubungan antar variabel independen dan dependen semakin baik. 


\section{Hasil dan Pembahasan}

\subsection{Deskripsi Responden}

Deskripsi responden akan dibagi berdasarkan jenis kelamin, usia, dan masa kerja. Deskripsi respoden berdasarkan jenis kelamin disajikan pada tabel 1 berikut ini:

Tabel 1. Deskripsi Responden Berdasarkan Jenis Kelamin

\begin{tabular}{c|c|c|}
\hline Keterangan & Jumlah & Persentase (\%) \\
\hline Laki-Laki & 60 & 56,07 \\
Perempuan & 47 & 43,93 \\
Jumlah & 107 & 100 \\
\hline
\end{tabular}

Sumber: Data Diolah (2021)

Pada tabel 1 tersaji informasi bahwa mayoritas responden berjenis kelamin laki-laki dengan persentase sebesar 56,07\% atau 60 orang dari total responden sebanyak 107 orang. Sedangkan sisanya berjenis kelamin perempuan yaitu 47orang atau 43,93\%. Selain jenis kelamin, responden dideskripsikan juga berdasarkan usia. Secara rinci ditampilkan pada tabel 2 berikut ini:

Tabel 2. Karakteristik Responden Berdasarkan Usia

\begin{tabular}{c|c|c|}
\hline Keterangan & Jumlah & Persentase (\%) \\
\hline 21-30 Tahun & 20 & 18,7 \\
31-40 Tahun & 80 & 74,8 \\
41-50 Tahun & 7 & 6,5 \\
Jumlah & 107 & 100 \\
\hline
\end{tabular}

Sumber: Data Diolah (2021)

Pada tabel 2, dapat dilihat bahwa kategori usia 31-40 tahun merupakan klaster usia yang paling besar yaitu 74,8\% dari total responden. Kemudian, kategori usia 2030 tahun sebesar 18,7\% dan sisanya merupakan klaster usia 41-50 tahun. Selain itu, responden juga diklasterisasi berdasarkan masa kerja. Masa kerja 1-3 tahun merupakan klaster responden yang paling dominan yaitu 98 responden dari total 107 responden. Secara rinci ditampilkan pada tabel 3 berikut ini:

Tabel 3. Karakteristik Responden Berdasarkan Masa Kerja

\begin{tabular}{c|c|c|}
\hline Keterangan & Jumlah & Persentase (\%) \\
\hline 1-3 Tahun & 98 & 91,6 \\
4-6 Tahun & 9 & 8,4 \\
Jumlah & 107 & 100 \\
\hline
\end{tabular}

Sumber: Data Diolah (2021)

\subsection{Uji Validitas}

Pada tahapan uji instrumen, penelitian ini menggunakan uji validitas dan uji reliabilitas. Sebuah konstruk dikatakan valid apabila nilai factor loading-nya lebih dari 0,5 dan berkumpul pada satu komponen dan tidak terjadi cross loading antar komponen di setiap konstruk. Secara rinci hasil uji validitas terjadi pada tabel 4 berikut ini: 
Tabel 4. Hasil Uji Validitas

\begin{tabular}{|c|c|c|c|}
\hline Indikator & & tor Loading & \\
\hline LK 1 & 0,727 & & \\
\hline LK 2 & 0,848 & & \\
\hline LK 3 & 0,831 & & \\
\hline LK 4 & 0,699 & & \\
\hline LK 5 & 0,747 & & \\
\hline ED 1 & & 0,806 & \\
\hline ED 2 & & 0,657 & \\
\hline ED 3 & & 0,841 & \\
\hline ED 4 & & 0,836 & \\
\hline ED 5 & & 0,732 & \\
\hline KN 1 & & & 0,675 \\
\hline KN 2 & & & 0,819 \\
\hline KN 3 & & & 0,782 \\
\hline KN 4 & & & 0,797 \\
\hline KN 5 & & & 0,767 \\
\hline KN 6 & & & 0,612 \\
\hline KN 7 & & & 0,769 \\
\hline
\end{tabular}

Sumber: Data Diolah (2021)

Nilai factor loading pada tabel 4 berada di atas standar yang telah ditentukan yaitu $\geq 0,5$. Nilai factor loading terendah adalah 0,612 pada indikator kinerja (KN 6), sedangkan nilai tertinggi diperoleh dari indikator lingkungan kinerja (LK 2). Selain itu, hasil menunjukkan bahwa tidak terjadi cross loading antar indikator.

\subsection{Uji Reliabilitas}

Pengujian instrumen selanjutnya adalah uji reliabilitas. Suatu instrumen dikatakan reliabel apabila memiliki nilai cronbach's alpha $\geq 0,6$ (Hair et al., 2009). Berdasarkan hasil yang diperoleh, nilai cronbach's alpha dari ketiga variabel, diperoleh masing-masing nilai cronbach's alpha untuk lingkungan kerja sebesar 0,831, efikasi diri sebesar 0,835, dan variabel dependen penelitian ini sebesar 0,868. Oleh karena itu dapat disimpulkan bahwa semua variabel penelitian dikatakan reliabel. Secara rinci disajikan pada tabel 5 berikut ini:

Tabel 5. Hasil Uji Reliabilitas

\begin{tabular}{cc|}
\hline Variabel & Cronbach's Alpha \\
\hline Lingkungan Kerja & 0,831 \\
Efikasi Diri & 0,835 \\
Kinerja & 0,868 \\
\hline
\end{tabular}

Sumber: Data Diolah (2021) 


\subsection{Uji Hipotesis}

Pada penelitian ini terdapat dua hipotesis yang akan diuji. Hipotesis pertama adalah pengaruh positif lingkungan kerja terhadap kinerja karyawan dan hipotesis kedua adalah pengaruh positif efikasi diri terhadap kinerja karyawan. Langkah awal adalah melakukan analisis nilai koefisien determinasi. Berdasarkan hasil statistik diperoleh nilai koefisien determinasi sebesar 12,8\%. Nilai tersebut berarti bahwa variasi variabel independen dalam penelitian ini hanya dapat menjelaskan $12,8 \%$ terhadap variabel dependen.

Hasil yang diperoleh, bahwa secara simultan lingkungan kerja dan efikasi diri mempengaruhi kinerja karyawan yang berkerja di Klenteng Sam Poo Kong dan Lawang Sewu. Hal tersebut dapat dilihat pada perbandingan nilai f-hitung dan nilai ftabel. Apabila nilai f-hitung > f-tabel, maka semua variabel independen memiliki pengaruh yang signifikan terhadap variabel dependen. Berdasarkan hasil statistik, nilai f-hitung sebesar 9,068 atau lebih besar dari f-tabel yaitu sebesar 3,084, dan hasil signifikansi berada pada level $\mathrm{P}<0,01$.

Selain itu, untuk menentukan hasil pengujian hipotesis, nilai statistik yang dapat diperhatikan adalah perbandingan nilai t-hitung dan nilai t-tabel serta level signifikansi. Hipotesis pertama mengatakan pengaruh positif lingkungan kerja terhadap kinerja karyawan. Nilai t-hitung yang diperoleh sebesar 2,080, atau lebih besar dibanding dengan nilai t-tabel sebesar 1,983 dengan level signifikansi $\mathrm{P}>0,01$. Oleh karena itu, hipotesis pertama diterima. Hal yang sama dengan hipotesis kedua, pengaruh positif efikasi diri terhadap kinerja karyawan. Perbandingan nilai t-hitung dan t-tabel adalah 2,798 $>1,983$ dengan level signifikansi $\mathrm{P}>0,01$. Hal tersebut berarti bahwa hipotesis kedua diterima. Secara detail, hasil statistik nilai koefisien determinasi, uji simultan, dan uji hipotesis disajikan pada tabel 6 berikut ini:

Tabel 6. Hasil Uji Regresi

\begin{tabular}{|c|c|c|c|c|c|c|}
\hline \multirow[t]{2}{*}{ Hipotesis } & \multicolumn{5}{|c|}{ Nilai } & \multirow[t]{2}{*}{ Keterangan } \\
\hline & $\mathbf{R}^{2}$ & $\mathbf{F}$ & Beta & $\mathbf{t}$ & Sig. & \\
\hline $\begin{array}{c}\text { Lingkungan } \\
\text { Kerja } \rightarrow \\
\text { Kinerja }\end{array}$ & 0,128 & $9,068^{* *}$ & 0,151 & 2,080 & 0,003 & Diterima \\
\hline $\begin{array}{c}\text { Karyawan } \\
\text { Efikasi Diri } \\
\rightarrow \text { Kinerja } \\
\text { Karyawan }\end{array}$ & & & 0,204 & 2,796 & 0,004 & Diterima \\
\hline
\end{tabular}




\subsection{Pembahasan}

\subsubsection{Pengaruh Positif Lingkungan Kerja terhadap Kinerja Karyawan}

Hasil statistik yang diperoleh menguatkan temuan penelitan sebelumnya. Chandrasekar (2011), Anitha (2014), Schultz \& Schultz (2016), dan Agbozo et al. (2017) menemukan hasil bahwa lingkungan kerja yang baik akan memberikan pengaruh terhadap peningkatan kinerja. Tata letak, ventilasi, dan ruang kerja yang nyaman, secara fisik mampu memberikan energi positif dan secara psikologis dapat menstimulus karyawan untuk mengeluarkan kemampuan terbaiknya dalam menyelesaikan tugas. Westerman \& Simmons (2007) menjelaskan bahwa orientasi tujuan, hubungan antar kolega dan sistem pemeliharaan dalam organisasi merupakan preferensi lingkungan kerja yang mampu menciptakan komitmen dan peningkatan perilaku dalam mencapai kinerja individual.

\subsubsection{Pengaruh Positif Efikasi Diri terhadap Kinerja Karyawan}

Hasil yang sama juga diperoleh untuk hipotesis kedua. Temuan penelitian ini semakin menguatkan hasil penelitian sebelumnya yang menyatakan bahwa efikasi diri memberikan pengaruh positif terhadap kinerja karyawan (Cherian \& Jacob, 2013; Carter et al., 2018; dan Redifer et al., 2021). Efikasi diri memilik efek adaptif terhadap kinerja karyawan. Semakin tinggi efikasi diri karyawan, maka kinerja akan mengalami peningkatan. Temuan lain dalam meta analisis yang dilakukan oleh Iroegbu (2015) bahwa efikasi diri bisa berpengaruh langsung maupun tidak langsung terhadap kinerja. Hal tersebut akan diperoleh berdasarkan kondisi lingkungan sosial karyawan.

\section{Kesimpulan dan Saran}

\subsection{Kesimpulan}

Berdasarkan temuan dalam penelitian, dapat disimpulkan bahwa organisasi sedapat mungkin untuk menjaga kondisi lingkungan kerja yang di Klenteng Sam Poo Kong dan Lawang Sewu. Selain untuk memberikan rasa nyaman bagi karyawan, hal tersebut juga dapat mempengaruhi iklim kerja antar karyawan maupun antara karyawan dan atasan. Lingkungan kerja yang kondusif, baik dari aspek fisik, psikologis maupun sosial terbukti dapat meningkatkan kinerja karyawan. Selain lingkungan kerja, efikasi diri karyawan juga perlu dibentuk. Temuan empiris penilitian ini semakin menguatkan bahwa efikasi diri karyawan menjadi faktor penting dalam meningkatkan kinerja karyawan yang secara langsung akan berpengaruh pada kinerja organisasi.

\subsection{Saran}

Penelitian ini berhasil menguatkan penelitian sebelumnya. Namun ada beberapa catatan yang bisa dipertimbangkan untuk lebih menguatkan kinerja karyawan dilihat dari perspektif lingkungan kerja dan efikasi diri. Pertama, penelitian berikutnya bisa mempertimbangkan keterlibatan karyawan (employee engagement) secara spesifik dalam menentukan kinerja. Variabel tersebut dapat diposisikan sebagai variabel moderasi. Kedua, penelitian ini dilakukan pada saat Kota Semarang menerapkan program Pemberlakuan Pembatasan Kegiatan Masyarakat (PPKM) yang merupakan kebijakan dalam menghadapi pandemi Covid-19. Hal tersebut berpotensi memberikan hasil temuan yang berbeda apabila tidak terjadi pembatasan kegiatan masyarakat. Oleh karena itu, penelitian selanjutnya bisa melakukan longitudinal study dengan objek yang lebih heterogen. 


\section{Daftar Pustaka}

Agbozo, G. K., Owusu, I. S., Hoedoafia, M. A., \& Atakorah, Y. B. (2017). The Effect of Work Environment on Job Satisfaction: Evidence from The Banking Sector in Ghana. Journal of Human Resource Management, 5(1), 12-18.

Ali, M. S. Y., \& Hasaballah, A. H. A. (2020). Assessing The Effect of Organizational Cultural Values and Employees Engagement on Performance Excellence. International Journal of Management, 11(4).

Anitha, J. (2014). Determinants of Employee Engagement and Their Impact on Employee Performance. International Journal of Productivity and Performance Management, 63(3), 308-323.

Bandura, A. (2012). On The Functional Properties of Perceived Self-Efficacy Revisited. Journal of Management, 38(1), 9-44.

Carter, W. R., Nesbit, P. L., Badham, R. J., Parker, S. K., \& Sung, L. K. (2018). The Effects of Employee Engagement and Self-Efficacy on Job Performance: A Longitudinal Field Study. International Journal of Human Resource Management, 29(17), 2483-2502.

Chandrasekar, K. (2011). Workplace Environment and Its Impact on Organisational Performance in Public Sector Organisations. International Journal of Enterprise Computing and Business Systems, 1(1), 1-19.

Cherian, J., \& Jacob, J. (2013). Impact of Self Efficacy on Motivation and Performance of Employees. International Journal of Business and Management, 8(14), 80-88.

Danish, R. Q., Ramzan, S., \& Ahmad, F. (2013). Effect of Perceived Organizational Support and Work Environment on Organizational Commitment; Mediating Role of Self-Monitoring. Advances in Economics and Business, 1(4), 312-317.

Dul, J., \& Ceylan, C. (2014). The Impact of A Creativity-Supporting Work Environment on A Firm's Product Innovation Performance. Journal of Product Innovation Management, 31(6), 1254-1267.

Frayne, C. A., \& Geringer, J. M. (2000). Self-Management Training for Improving Job Performance: A field Experiment Involving Salespeople. Journal of Applied Psychology, 85(3), 361-372.

Hair, J. F. J., Black, W. C., Babin, B. J., \& Anderson, R. E. (2009). Multivariate Data Analysis. 7th Edition. Pearson.

Iroegbu, M. N. (2015). Self Efficacy and Work Performance: A Theoretical Framework of Albert Bandura's Model: Review of Findings, Implications and Directions for Future Research. Psychology and Behavioral Sciences, 4(4), 170.

Kacmar, K. M., Collins, B. J., Harris, K. J., \& Judge, T. A. (2009). Core Self-Evaluations and Job Performance: The Role of the Perceived Work Environment. Journal of Applied Psychology, 94(6), 1572. 
Kempiak, J., Hollywood, L., Bolan, P., \& Mcmahon-Beattie, U. (2017). The Heritage Tourist: An Understanding of The Visitor Experience at Heritage Attractions. International Journal of Heritage Studies, 23(4), 375-392.

Lamb, S., \& Kwok, K. C. (2016). A Longitudinal Investigation of Work Environment Stressors on The Performance and Wellbeing of Office Workers. Applied Ergonomics, 52, 104111.

Morin, L., \& Latham, G. P. P. (2000). The Effect of Mental Practice and Goal Setting as A Transfer of Training Intervention on Supervisors Self-Efficacy and Communication Skills: An Exploratory Study. Applied Psychology, 49(3), 566-578.

Poria, Y., Butler, R., \& Airey, D. (2004). Links between Tourists , Heritage , and Reasons for Visiting Heritage Sites. Journal of Travel Research, 43(1), 19-28.

Ram, P., \& Prabhakar, G. V. (2011). The Role of Employee Engagement in Work-Related Outcomes. Interdisciplinary Journal of Research in Business, 1(3), 47-61.

Redifer, J. L., Bae, C. L., \& Zhao, Q. (2021). Self-Efficacy and Performance Feedback: Impacts on Cognitive Load during Creative Thinking. Learning and Instruction, 71, 101395.

Robbins, S. P., \& Judge, T. (2015). Perilaku Organisasi. Salemba Empat.

Schmidt, A. M., \& DeShon, R. P. (2010). The Moderating Effects of Performance Ambiguity on the Relationship Between Self-Efficacy and Performance. Journal of Applied Psychology, 95(3), 572.

Schultz, D. P., \& Schultz, S. E. (2016). Theories of Personality. Cengage Learning.

Sugiyono. (2012). Metode Penelitian Kuantitatif, Kualitatif, dan R\&D. Alfabeta.

Supriyanto, A. S., \& Ekowati, V. M. (2020). Linking Work Environment to Employee Performance: The Mediating Role of Work Discipline. BISMA (Bisnis dan Manajemen), 13(1), 14-25.

Talsma, K., Schüz, B., \& Norris, K. (2019). Miscalibration of Self-Efficacy and Academic Performance: Self-Efficacy $\neq$ Self-Fulfilling Prophecy. Learning and Individual Differences, 69, 182-195.

Tzur, K. S., Ganzach, Y., \& Pazy, A. (2016). On The Positive and Negative Effects of SelfEfficacy on Performance: Reward as A Moderator. Human Performance, 29(5), 362377.

Westerman, J. W., \& Simmons, B. L. (2007). The Effects of Work Environment on The Personality-Performance Relationship: An Exploratory Study. Journal of Managerial Issues, 288-305. 